\title{
THE USE OF A NEW CETRIMIDE PRODUCT IN A SELECTIVE MEDIUM FOR PSEUDOMONAS PYOCYANEA
}

\author{
BY \\ E. J. L. LOWBURY AND A. G. COLLINS \\ From the Medical Research Council Industrial Injuries and Burns Research Unit, Birmingham Accident \\ Hospital
}

(RECEIVED FOR PUbLication May 7, 1954)

A selective medium containing $0.1 \%$ cetrimide in nutrient agar has been used here during the past four years for the routine identification of Ps. pyocyanea in burns (Lowbury, 1951). This medium, a modification of those previously described by Harper and Cawston (1945) and by Hood (1948), has proved convenient and efficient.

In October, 1953, the manufacturers announced the production of a modified "cetavlon" which was claimed to be more active against Ps. pyocyanea than the old product, and little less active against that organism than against Proteus vulgaris. In view of these observations we have made the following tests to find whether the new cetrimide is suitable for use in a selective medium for Ps. pyocyanea, and if so at what concentration it should be included.

\section{Choice of a Dilution of the New Cetrimide for the Selective Medium}

Media containing the old and the new cetrimide were compared by methods described by one of us in a previous paper (Lowbury, 1951).

The basic medium was "lemco" agar at $p \mathrm{H} 7.8$ (" oxoid lab. lemco," 1.0 g., " oxoid" peptone, 1.0 g., sodium chloride, $0.5 \mathrm{~g}$., Davis agar, $1.5 \mathrm{~g}$.,

TABLE

EXAMINATION OF 500 BURN SWABS WITH OLD AND NEW CETRIMIDE AGAR

\begin{tabular}{|c|c|c|c|c|c|c|}
\hline \multirow{3}{*}{ Medium* } & \multicolumn{6}{|c|}{ Ps. pyocyanea Isolated on } \\
\hline & \multicolumn{3}{|c|}{$\begin{array}{c}\text { Direct } \\
\text { Plating of Swabs }\end{array}$} & \multicolumn{3}{|c|}{$\begin{array}{c}\text { Subculture } \\
\text { from Fluid Medium }\end{array}$} \\
\hline & \begin{tabular}{|} 
Positive \\
at 18 hrs.
\end{tabular} & $\begin{array}{l}\text { Positive } \\
\text { at } 48 \mathrm{hrs} \text {. }\end{array}$ & $\begin{array}{c}\text { Total } \\
+\end{array}$ & \begin{tabular}{|} 
Positive \\
at 18 hrs.
\end{tabular} & Positive & $\begin{array}{c}\text { Total } \\
+\end{array}$ \\
\hline $\begin{array}{l}\text { Agar with new } \\
\text { cetrimide } \\
(0.03 \%) \\
\text { Agar with oid } \\
\text { cetrimide } \\
(0.1 \%)\end{array}$ & 116 & 50 & 166 & 230 & 13 & $\begin{array}{l}243 \\
242\end{array}$ \\
\hline
\end{tabular}

- The order of inoculating these media was reversed with successive swabs to make the two series comparable. and tap water $100 \mathrm{ml}$.). The quality of growth, pigment, and fluorescence of Ps. pyocyanea was somewhat improved by the addition of a phosphate buffer to this medium. A series of dilutions of the new cetrimide, from $0.01 \%$ to $0.1 \%$, was incorporated in the basic medium, and these were compared with the old cetrimide agar $(0.1 \%)$ in respect of $(a)$ ability to inhibit the growth of Proteus vulgaris, coliform bacilli, and some other organisms, $(b)$ the growth of large and small inocula of Ps. pyocyanea, and (c) the isolation of Ps. pyocyanea from burns.

The lowest concentration of new cetrimide sufficiently selective for use in the medium was found to be $0.03 \%$. A trial of this medium on swabs taken from burns (see Table) showed that it was at least as effective in showing the presence of Ps. pyocyanea as the old medium. Ps. pyocyanea was recognized by the production of a green pigment, or of fluorescence under ultra-violet irradiation, or of both (Lowbury, 1951). Colonies of Ps. pyocyanea were larger on the new medium than on the old, and the proportion of isolations obtained after overnight incubation was also greater with the new medium. With cetrimide at a concentration of $0.04 \%$, however, the growth of Ps. pyocyanea from swabs was poor, and small inocula often failed to grow. From these observations we inferred that the optimal concentration of the new cetrimide was $0.03 \%$.

\section{Comments}

Ringen and Drake (1952) recently described the use of pyocyanin in a fluid selective medium for $P$ s. pyocyanea. We have made tests with agar media containing up to $0.05 \%$ pyocyanin, and found that they were no more selective for Ps. pyocyanea than cetrimide agar. They were, moreover, unsatisfactory in use because the characteristic pigment by which Ps. pyocyanea is identified could not be seen. 
Occasionally Ps. pyocyanea on cetrimide agar has been found to lose its fluorescence under ultraviolet irradiation after standing for a short time on the bench. It reappeared, however, when the plates were reincubated.

As cetrimide, even in its new form, is not a pure compound, we recommend that new batches should be tested to establish the optimal concentration required in the selective medium for Ps. pyocyanea.

\section{Summary}

A trial on burn swabs has shown that the optimal concentration of a new cetrimide product in a selective medium for Ps. pyocyanea is $0.03 \%$ Growth, fluorescence, and pigment production of this medium could be improved by inclusion of $\frac{\mathrm{S}_{\mathrm{a}}}{\mathrm{a}}$ phosphate buffer at $p \mathrm{H} \mathbf{7 . 8}$.

We wish to thank Imperial Chemical (Pharm ceuticals), Ltd., for information about the negv "cetavlon," and Dr. A. C. Cunliffe for strains of Proteus vulgaris.

\section{REFERENCES}

Harper, G. J., and Cawston, W. C. (1945). Bull. Inst. med. L Techn., 11, 40.

Hood, A. M. (1948). Monthly Bull. Minist. Hlth, Lond., 7. 248. Lowbury, E. J. (1951). Journal of Clinical Pathology, 4, 66. Ringen, L. M., and Drake, C. H. (1952). J. Bact., 64, 841. 